\title{
INTEGRASI SISTEM PERENCANAAN, PENGANGGARAN DAN MANAJEMEN KINERJA: SEBUAH BEST PRACTICE DI BANK INDONESIA ${ }^{1}$
}

\author{
Mariman Darto \\ Peneliti Madya pada Bidang Kajian Aparatur, PKP2A III LAN \\ JI. H.M. Ardans, SH. (Ring Road III) Samarinda \\ Email :marimandarto@yahoo.com; marimandarto@gmail.com
}

\begin{abstract}
Since 1999, efforts to change to the application of performance management systems are integrated with planning and budgeting systems in Bank Indonesia continues to be done. This effort is taken to maintain the continuity and sustainability of the achievement of organizational goals and the achievement of optimal high-performance organization. Systems Planning, Budget and Performance Management (SPAMK) based on the Balanced Scorecard (BSC) initially encountered many obstacles. Generally, the constraints are not on the technical aspects, but rather on non-technical aspects such as culture and behavior. The key to successful integration of planning and budgeting systems with performance management at Bank Indonesia lies in the changing work culture and mindset. Nevertheless, changes in work processes through integration with information technology (information technology) are also important. By using a search technique a variety of documents / literature (documentary research) and through several stages of workshops held both in the Bank Indonesia and the LAN as well as in other institutions, this study managed to dig up important information related to the possible application in government institution. The main purpose of this paper is to find out how the integration of planning, budgeting and performance management at Bank Indonesia. In addition, to find out how the impact caused by the application of these SPAMK and possible application in the government environment.
\end{abstract}

Keywords: Strategic Planning, Budgeting, Performance Management, Balanced Scorecard, Key Performance Indicators

\section{Intisari}

Sejak 1999, upaya perubahan terhadap penerapan sistem manajemen kinerja yang terintegrasi dengan sistem perencanaan dan penganggaran di Bank Indonesia terus dilakukan. Upaya ini ditempuh untuk menjaga

${ }^{1}$ Naskah diterima: 16 November 2011, revisi kesatu: 3 Desember 2011, revisi terakhir: 5 Desember 2011 
kontinuitas dan keberlanjutan pencapaian tujuan organisasi secara optimal dan pencapaian kinerja organisasi yang tinggi. Sistem Perencanaan, Anggaran, dan Manajemen Kinerja (SPAMK) yang berbasis Balanced Scorecard (BSC) pada awalnya menemui banyak kendala. Umumnya, kendala tersebut bukan pada aspek teknis, namun lebih pada non teknis seperti aspek budaya dan perilaku. Kunci sukses integrasi sistem perencanaan dan penganggaran dengan manajemen kinerja di Bank Indonesia terletak pada perubahan budaya kerja dan pola pikir. Meskipun demikian, perubahan pada proses kerja melalui integrasi dengan teknologi informasi (information technology) juga penting. Dengan menggunakan teknik penelusuran berbagai dokumen/literatur (documentary research) dan melalui beberapa tahap workshop yang diselenggarakan baik di Bank Indonesia dan LAN maupun di instansi lain, kajian ini berhasil menggali informasi penting terkait dengan kemungkinan penerapannya di intansi pemerintah. Tujuan utama dari penulisan ini adalah mengetahui bagaimana integrasi sistem perencanaan, penganggaran dan manajemen kinerja di Bank Indonesia. Selain itu juga untuk mengetahui bagaimana dampak yang ditimbulkan akibat penerapan SPAMK tersebut dan kemungkinan penerapannya di lingkungan pemerintah.

Kata kunci : Perencanaan Strategis, Penganggaran, Manajemen Kinerja, Balanced Scorecard, Indikator Kinerja Utama

\section{A. PENDAhULUAN}

Sistem perencanaan, penganggaran dan manajemen kinerja yang terintegrasi menjadi tuntutan manajemen pemerintahan ke depan, sekaligus merupakan proses yang krusial dalam penyelenggaraan pemerintahan. Selain karena perencanaan dan penganggaran merupakan rangkaian kegiatan dalam satu kesatuan atau kontinum, keduanya juga terkait dengan pencapaian tujuan organisasi pemerintah. Perencanaan dan penganggaran merupakan proses yang terintegrasi, oleh karenanya output dari perencanaan adalah penganggaran (Bastian, 2006). Sedangkan manajemen kinerja merupakan tatakelola pencapaian tujuan organisasi sesuai dengan dokumen perencanaan dan penganggaran yang ditetapkan organisasi. Atau dalam istilah lain manajemen kinerja sebagai tatakelola perilaku dan hasil kerja seseorang dalam pencapaian tujuan organisasi (Bates dan Holton, 1995; Amstrong, 1994; Waal, 2007; dan Brumbach, 1988).

Integrasi ketiga proses manajemen ini telah mendapatkan momentumnya dengan lahirnya berbagai peraturan perundangundangan yang terkait dengan peningkatan kinerja sektor publik, yaitu : Inpres 7/1999 tentang Akuntabilitas Kinerja Instansi Pemerintah, PP 108/2000 tentang Tatacara Pertanggungjawaban Kepala Daerah, UU No. 17 Tahun 2003 tentang Keuangan Negara; UU No. 25 Tahun tentang Pemerintahan Daerah; UU No. 33 Tahun 2004 tentang Perimbangan 
Keuangan Pusat dan Daerah. Tidak cukup dengan itu, UU No. 1 Tahun 2004 tentang Perbendaharaan Negara; UU No. 15 Tahun 2004 tentang Pemeriksaan Pengelolaan dan Tanggungjawab Keuangan Negara; PP No. 20 Tahun 2004 tentang Rencana Kerja Pemerintah; Instruksi Presiden RI No. 5 Tahun 2004 tentang Percepatan Pemberantasan Korupsi; PP No. 21 Tahun 2004 tentang Rencana Kegiatan dan Anggaran Kementerian Negara/Lembaga; PP No. 58 Tahun 2005 tentang Pengelolaan Keuangan Negara; PP No. 8 Tahun 2006 tentang Pelaporan Keuangan dan Kinerja Instansi Pemerintah; PP No. 8 Tahun 2008 tentang Tahapan, Tatacara Penyusunan, Pengendalian dan Evaluasi Pelaksanaan Rencana Pembangunan Daerah; Surat Edaran Menpan No. SE/31/M.PAN/12/2004 perihal Penetapan Kinerja; Permenpan No. 29 Tahun 2010 tentang Pedoman Penyusunan Penetapan Kinerja dan Pelaporan Akuntabilitas Kinerja Instansi Pemerintah. Bahkan ketiganya mencapai puncaknya sejak lahirnya Perpres No. 81 Tahun 2010 tentang Grand Design Reformasi Birokrasi Tahun 2010-2025.

Di Indonesia, model integrasi sistem perencanaan, penganggaran dan manajemen kinerjanya telah dibangun sejak 1999, yang ditandai dengan lahirnya Inpres 7/1999 tentang Akuntabilitas Kinerja Instansi Pemerintah yang dikenal dengan Sistem Akuntabilitas Kinerja Instansi Pemerintah (SAKIP). Namun demikian, proses pengembangan SAKIP dan Laporan Kinerja Instansi Pemerintah (LAKIP) berlangsung dalam rentang waktu yang cukup panjang antara 1995-1998. Dimulai dari inisiatif Badan Pengawas Keuangan dan Pembangunan (BPKP) dalam mengembangkan konsep akuntabilitas melalui berbagai kegiatan antara lain : (a) studi literatur, (b) pemaparan hasil studi, (c) seminar dan (d) inventarisasi berbagai masukan (LAN, 2005). Selanjutnya dalam tahun 1999, pemantapan pengembangan SAKIP dan LAKIP dilakukan secara inter-dep yang mencakup kementerian PAN, LAN, BPKP, Depdagri, Bappenas, Sekretariat Negara, Departemen Keuangan, dan BKN. Hasil upaya tersebut dituangkan dalam suatu kebijakan nasional dengan terbitnya Inpres No. 7 Tahun 1999 tentang Akuntabilitas Kinerja Instansi Pemerintah (AKIP), yang mewajibkan setiap instansi pemerintah sebagai unsur penyelenggara pemerintahan negara untuk mempertanggungjawabkan pelaksanaan tupoksinya serta kewenangan pengelolaan sumberdaya dengan didasarkan pada suatu rencana stratejik yang ditetapkan oleh masingmasing instansi.

Sayangnya, model integrasi yang ada masih menempatkan faktor (realisasi) keuangan (financial performance) sebagai dasar penilaian kinerja organisasi (LAN, 2006). Namun, setelah lahirnya PP No 8 Tahun 2006 tentang Pelaporan Keuangan dan Kinerja Instansi Pemerintah, konsep SAKIP mulai diarahkan pada managerial performance yang diintegrasikan dengan financial performance. Hingga saat ini, konsep penyempurnaan SAKIP tersebut tidak segera ditindaklanjuti dengan Perpres SAKIP sebagaimana diamanahkan di dalam PP No. 8 Tahun 2006 tersebut. 
Hal inilah yang melatarbelakangi Lembaga Administrasi Negara pada Tahun 2006 melakukan "Kajian Penyempurnaan Sakip sesuai dengan Terbitnya PP No. 8 Tahun 2006 tentang Pelaporan Keuangan dan Kinerja Instansi Pemerintah". Hasil kajian ini makin memperjelas posisi SAKIP sebagai suatu sistem yang utuh yang mampu meningkatkan akuntabilitas publik instansi pemerintah dengan suatu laporan kinerja yang menyediakan informasi kinerja instansi pemerintah yang menunjukkan pencapaian kinerja organisasi dalam rangka pencapaian misi dan visi organisasi.

Tuntutan reformasi birokrasi melahirkan kesadaran pentingnya berakuntabilitas dengan menempatkan kinerja organisasi sebagai cara memenuhi tuntutan publik tersebut. Pada tahun 2007, untuk pertamakalinya pemerintah menetapkan pilot project program reformasi birokrasi pada tiga instansi pusat yaitu Kementerian Keuangan (dulu Departemen Keuangan), Mahkamah Agung, dan Badan Pemeriksa Keuangan (BPK). Salah satu poin penting yang mereka laksanakan adalah perubahan sistem manajemen kinerja yang berbasis Balanced Scorecard (BSC).

Atas pertimbangan ini, pada t a h u n 2008 L A N un tuk mengembangkan Pedoman Penerapan Manajemen Kinerja bagi Instansi Pemerintah, melalui Kajian Penyusunan Pedoman Penerapan Manajemen Kinerja bagi Instansi Pemerintah (LAN, 2008). Konsep ini kemudian melahirkan enam modul utama yang dikembangkan setahun setelah itu (LAN, 2009), yang pada tahun 2010 diujicobakan di tiga provinsi yaitu Jawa Barat, Bali dan Kalimantan Selatan (LAN, 2010). Konsep manajemen kinerja ini juga didasari atas penggunaan BSC sebagai management tools yang mampu mengatasi berbagai kelemahan penerapan Renstra yang antara lain, Renstra tidak mampu diturunkan hingga ke bawah karena mekanisme pengkomunikasian strategi tidak dimiliki. Hal ini sangat berbeda jika manajemen kinerja sebagai alat yang mampu menjembatani integrasi perencanaan dan penganggarannya dengan BSC sebagai penghubung dengan peta strategi yang memungkinkan fungsi-fungsi middle $\mathrm{dan}$ low manager dapat mengoperasikan strategi yang ditetapkan dalam perencanaan strategis organisasi.

Dalam uji coba tersebut masih ditemukan beberapa persoalan antara lain : pertama, kebijakan yang memayungi penerapan Manajemen Kinerja belum ada; kedua, konsep manajemen kinerja belum populer di daerah; ketiga, komitmen pimpinan terhadap penerapan manajemen kinerja rendah; keempat, ketidakjelasan Indikator Kinerja Utama (IKU), sehingga menimbulkan ketidakjelasan hasil yang ingin dicapai; dan kelima, pendekatan pembagian kegiatan tidak didasarkan pada tugas pokok dan fungsi tetapi lebih kepada pemerataan. Sejumlah kendala ini memang bisa dipahami karena sebagian mereka masih membutuhkan komitmen dan ketegasan kebijakan dari pemerintah pusat terkait dengan penerapan manajemen kinerja ini. 
Hal inilah yang kemudian membuat penulis tertarik untuk mendalami praktek sistem manajemen kinerja di Bank Indonesia. Ada beberapa alasan penting yang bisa diajukan : pertama, Bank Indonesia tegolong sektor publik, sehingga sistem manajemen kinerja yang akan diterapkan di Instansi pemerintah juga tidak akan banyak menemui kendala. Kedua, penerapan Balanced Scorecard, sebuah perangkan manajemen yang sebenarnya banyak diterapkan di sektor swasta ternyata di Bank Indonesia, juga bisa diterapkan. Karena itu, penerapannya di instansi pemerintah pun juga bisa digunakan. Ketiga, jika Bank Indonesia sejak awal menghadapi kondisi buruknya cultureset dan mind set di lingkungan kerjanya, di instansi pemerintah pun juga mengalami hal yang tidak berbeda. Hal inilah yang mendorong penulis untuk melakukan eksplorasi mendalam tentang praktek manajemen kinerja di Bank Indonesia.

Adapun tujuan dari penulisan paper singkat ini adalah untuk mengetahui bagaimana integrasi sistem perencanaan, penganggaran dan manajemen kinerja di Bank Indonesia.

\section{B. METODE PENELITIAN}

Penelitian ini merupakan penelitian kualitatif dengan pendekatan pengumpulan datanya dilakukan melalui penelusuran dokument (documentary research) terkait berbagai data skunder baik dari hasil penelitian yang relevan seperti yang dilakukan LAN (2005, 2006, 2008, 2009 dan 2010), Bappenas (2006), berbagai buku teks tentang perencanaan, penganggaran dan manajemen kinerja, maupun melalui kegiatan workshop, baik yang dilakukan oleh Bank Indonesia maupun oleh Lembaga Administrasi Negara, Kementerian Keuangan RI yang dilakukan pada kurun waktu 2004-2010. Teknik analisis yang digunakan adalah menganalisis praktek yang dilakukan oleh Bank Indonesia dengan mendeskripsikan apa yang telah dilakukan oleh BI dan dikaitkan dengan konteks kebijakan yang berkembang terkait dengan integrasi sistem perencanaan, penganggaran dan manajemen kinerja.

\section{KERANGKA KONSEP Konteks Kebijakan}

Di Indonesia, integrasi sistem perencanaan, penganggaran dan manajemen kinerja diawali dengan lahirnya Inpres 7/1999 tentang Akuntabilitas Kinerja Instansi Pemerintah, yang dalam perkembangannya, kebijakan ini melahirkan Sistem Akuntabilitas Kinerja Instansi Pemerintah (SAKIP). Inpres ini menginstruksikan kepada : Para Menteri; Panglima Tertinggi Nasional Indonesia; Gubernur Bank Indonesia; Jaksa Agung; Kepala Kepolisian Republik Indonesia; Para Pimpinan Lembaga Pemerintah Non Departemen; Para Pimpinan Sekretariat Lembaga Tertinggi dan Tinggi Negara; Para Gubernur; Para Bupati/Walikota, untuk melaksanakan akuntabilitas kinerja instansi pemerintah sebagai wujud pertanggungjawaban instansi pemerintah dalam mencapai misi dan tujuan organisasi. Dalam Inpres tersebut, akuntabilitas didefinisikan sebagai kewajiban untuk menyampaikan pertanggungjawaban 
atau untuk menjawab dan menerangkan kinerja dan tindakan seseorang/badan hukum/pimpinan kolektif suatu organisasi kepada pihak yang memiliki hak atau kewenangan untuk meminta keterangan atau pertanggungjawaban.

Sebagai bentuk tanggungjawab LAN yang telah melahirkan sistem AKIP tersebut, Kepala LAN menerbitkan SK Kepala LAN 589/IX/6/Y/1999 tentang Pedoman Penyusunan Pelaporan AKIP, yang kemudian disempurnakan dengan SK Kepala LAN No. 239/IX/6/8/2003 tentang perbaikan Pedoman Penyusunan Pelaporan AKIP, yang berisi tentang (1) perencanaan strategik, (2) perencanaan kinerja, (3) pengukuran kinerja, dan (4) pelaporan.

Dalam perkembangannya, SAKIP telah mendapat respon positif dari instansi pemerintah baik Pusat ma u u n a e rah. Da 1 a m penyelenggaraan pemerintahan daerah, telah diterbitkan PP 108/2000 tentang Tatacara Pertanggungjawaban Kepala Daerah, LAKIP yang disusun oleh para K e p a l a D i n s D a e $\mathrm{r}$ h Propinsi/Kabupaten/Kota merupakan akuntabilitas manajerial sebagaimana diinstruksikan oleh Inpres 7/1999. LAKIP tersebut sangat bermanfaat bagi Kepala Daerah dalam rangka menyusun pertanggungjawaban Kepala Daerah kepada DPRD. Dalam Pasal 4 PP 108/2000 antara lain bahwa (1) Pertanggungjawaban Kepala Daerah dinilai berdasarkan tolokukur Renstra. (2) Setiap Daerah wajib menetapkan Renstra dalam jangka waktu satu bulan setelah Kepala Daerah dilantik.
Dalam hal penilaian kinerja, ada kesamaan antara PP 108/2000 dengan SAKIP dan LAKIP seperti berikut ini : (1) Dampak, terhadap kondisi makro yang ingin dicapai berdasarkan manfaat yang dihasilkan; (2) Manfaat, kemanfaatan yang dapat dirasakan sebagai nilai tambah bagi masyarakat atau pemerintah; (3) Hasil, tingkat pencapaian kinerja yang diharapkan terwujud berdasarkan keluaran (output) kebijakan atau program yang sudah dilaksanakan; (4) Keluaran, bentuk produk yang dihasilkan langsung oleh kebijakan atau program berdasarkan input yang digunakan; dan (5) Input, tingkat atau besaran sumbersumber yang digunakan, sumberdaya manusia, dana, waktu, teknologi, dan sebagainya.

Dalam hal perencanaan anggaran, khususnya di daerah, telah diterbitkan Kepmendagri 29/2002 tentang Pedoman Pengurusan, Pertanggungjawaban, dan Pengawasan Keuangan Daerah, Serta Tatacara Penyusunan APBD, Pelaksanaan Tata Usaha Keuangan Daerah dan Penyusunan Perhitungan APBD, antara lain pada Pasal 19 yang menyatakan bahwa : (1) Arah dan Kebijakan Umum serta Strategi dan Prioritas APBD ditetapkan oleh Kepala Daerah sebagai pedoman bagi Perangkat Daerah dalam menyusun usulan Program, Kegiatan, dan Anggaran; (2) Usulan Program, Kegiatan, dan Anggaran disusun berdasarkan prinsip-prinsip anggaran kinerja. Makna pasal 19 dimaksud memiliki kesesuaian dengan konsep perencanaan dalam SAKIP tersebut.

Dengan semakin meningkatnya tuntutan masyarakat akan 
kepemerinthan yang baik, dalam kerangka pengelolaan keuangan negara pemerintah telah menerbitkan UU No. 17 tahun 2003 tentang Keuangan Negara. Dalam Pasal 14 ditegaskan, dalam rangka penyusunan APBN, Menteri/Pimpinan lembaga selaku pengguna anggaran/pengguna barang menyusun rencana kerja dan anggaran kementerian/lembaga.

Terdapat perubahan-perubahan yang mendasar dalam sistem pengelolaan keuangan negara sebagaimana diamanahkan dalam UU No. 17/2003 tersebut. Berbagai perubahan tersebut antara lain : (1) prinsip anggaran berimbang diganti dengan anggaran surplus/deficit; (2) program budgeting (berbasis tujuan) menjadi performance budgeting (berbasis kinerja); (3) anggaran yang disusun atas dasar rencana lima tahunan diganti menjadi anggaran yang disusun secara rolling dengan pendekatan Medium Term Expenditure Framework; dan (4) dual budget (rutin dan pembangunan) menjadi unified budget (satu anggaran). Salah satu aspek penting dalam upaya tersebut adalah Anggaran Berbasis Kinerja (ABK) yang merupakan sistem pengganggaran yang dapat memadukan perencanaan kinerja dan anggaran tahunan sehingga dapat diketahui keterkaitan antara dana yang tersedia dengan hasil (outcomes) yang diharapkan.

Dalam pelaksanaan anggaran berbasis kinerja dilakukan penyusunan Rencana Kerja dan Anggaran (RKA) berdasarkan prestasi kerja, disertai dengan prakiraan belanja untuk tahun berikutnya setelah tahun anggaran yang sedang disusun dengan prinsip anggaran terpadu/unified budget. Penerapan ABK ini sejalan dengan upaya membangun akuntabilitas publik, dengan fokus kepada pencapaian hasil (outcomes) sebagai isu sentralnya. Disinilah integrasi perencanaan dan penganggaran terjadi.

Untuk menindaklanjuti UU No. 17 Tahun 2003 telah dikeluarkan PP 20/2004 tentang Rencana Kerja Pemerintah (RKP) dimaksudkan sebagai upaya-upaya pemerintah secara menyeluruh untuk mewujudkan tujuan bernegara. RKP tidak hanya memuat kegiatan-kegiatan dalam kerangka investasi Pemerintah dan pelayanan publik, tetapi juga untuk menjalankan fungsi Pemerintah sebagai penentu kebijakan dengan menetapkan kerangka regulasi guna mendorong partisipasi masyarakat. Dalam Pasal 9 ayat (2) ditegaskan, Kepala Satuan Kerja sebagai kuasa pengguna anggaran bertanggungjawab atas pencapaian kinerja berupa barang dan/atau jasa dari kegiatan yang dilaksanakan satuan kerja yang bersangkutan; (3) Kementerian Negara/lembaga membuat laporan kinerja triwulanan, dan tahunan atas pelaksanaan rencana kerja dan anggaran yang berisi uraian tentang keluaran kegiatan dan indikator kinerja masing-masing program; (4) Laporan sebagaimana dimaksud dalam ayat (3), disampaikan kepada Kementerian Keuangan dan Kementerian Perencanaan paling lambat 14 (empat belas) hari setelah berakhirnya triwulan yang bersangkutan. Dalam Pasal 10 ayat (1) ditegaskan Kementerian Negara/ Lembaga melakukan evaluasi kinerja program paling sedikit (satu) 
kali dalam 5 (lima) tahun berdasarkan sasaran dan/atau standar kinerja yang telah ditetapkan. Dalam waktu yang bersamaan dikeluarkan PP 21/2004 tentang Penyusunan Rencana Kerja dan Anggaran Kementerian Negara/Lembaga (RKA-KL).

Selanjutnya dalam UU No. 1/2004 tentang Perbendaharaan Negara, ditegaskan, Menteri/Pimpinan Lembaga, selaku pengguna anggaran/pengguna barang berwenang antara lain menyusun dokumen pelaksanaan anggaran yang meliputi sasaran yang hendak dicapai, fungsi, program, dan rincian kegiatan.

Melengkapi kebijakan bidang keuangan negara dan perbendaharaan negara, perubahan dalam kerangka sistem perencanaan nasional lahir sebagai upaya untuk memperkuat integrasi sistem perencanaan dan penganggaran, dengan terbitnya UU 25/2004 tentang Sistem Perencanaan Pembangunan Nasional. Salah satu pendekatan penting dalam menjamin kesinambungan pembangunan nasional adalah mendorong efektivitas dan efisiensi, melalui proses sinkronisasi dan peningkatan sinergi antara pemerintah Pusat dengan Daerah, serta program pembangunan lintas sektor di Daerah.

Dalam hal penyusunan perencanaan di daerah, UU 25/2004 pada Pasal 1, ditegaskan bahwa institusi/lembaga perencanaan di tingkat pusat adalah Badan Perencanaan Pembangunan Nasional (BAPPENAS), Sedangkan di tingkat daerah institusi / le mbaga perencanaannya adalah Badan
Perencanaan Pembangunan Daerah (BAPPEDA). Keduanya lahir sebagai salah satu upaya untuk meningkatkan efektifitas dan efisiensi pengelolaan sumberdaya yang makin terbatas.

Dalam kajian LAN tahun 2005, "Kajian Evaluasi Kebijakan Pengembangan dan Pelaksanaan Sakip dan Lakip, disebutkan bahwa komoponen Sakip yang terpenting adalah Renstra sebagai dokumen perencanaan strategis sebuah organisasi. Namun dalam perkembangan kebijakan, konsep ini timbul tenggelam dan keberadaannya makin "tidak diperhitungkan". Perkembangan konsep SAKIP (LAN, 2005), khususnya terkait dengan Renstra yang memilik muatan materi antara lain : (a) visi; (b) misi, (c) tujuan, (d) sasaran, (e) strategi (komponen strategi terdiri dari kebijakan dan program) serta rencana kinerja, yang terdiri dari (a) sasaran, (b) program, (c) kegiatan, dan indikator kinerja kegiatan sebagaimana tertuang dalam Lampiran Inpres 7/1999 dan dijelaskan dalam Pedoman Kepala LAN sebagai operasionalisasi konsep SAKIP yang tertuang dalam modul SAKIP. Dalam UU No. 17/2003 tentang Keuangan Negara, tidak menyebutkan adanya Renstra, akan tetapi rencana kerja anggaran dan rencana kerja yang tidak menyebutkan secara eksplisit tentang sistimatika RKA. Dalam PP No.20/2004 diamanatkan adanya Renstra-KL (RPJM - 5 tahunan) yang memuat: (a) visi, (b) misi, (c) tujuan, (d) strategi, (e) kebijakan, (f), program, dan $(\mathrm{g})$ kegiatan pembangunan. Dalam PP No. 21/2004 diamanatkan adanya RKA-KL, yang memuat (a) visi, (b) misi, (c) tujuan, (d) kebijakan, 
(e) program, (f) kegiatan, (g) keluaran. Sedangkan dalam UU No.25/2004 diamanatkan adanya (1) Renstra-KL (RPJM - 5 tahunan) yang memuat : a) visi, b) misi, c) tujuan, d) strategi, e) kebijakan, f) program, g) kegiatan pembangunan; (2) Renstra -SKPD (RPJM-SKPD， 5 tahunan) yang memuat : a) visi, b) misi, c) tujua, d) strategi, e) kebijakan, f) program, g) kegiatan pembangunan; (4) Rencana kerja KL (Renja-KL, 1 tahunan) yang memuat : a) nama unit organisasi, b) program, c) kegiatan; (4) Rencana kerja SKPD (Renja-SKPD, 1 tahunan) yang memuat : a) nama unit organisasi, b) program, c) kegiatan. Dengan mencermati rencana strategi yang diamanatkan oleh berbagai peraturan perundangan tersebut terdapat adanya persepsi yang berbeda secara substansi dan mendasar. Oleh karena itu, melalui kegiatan tahun anggaran 2005, LAN RI melakukan evaluasi kebijakan pengembangan dan pelaksanaan SAKIP dan LAKIP, yang mencakup seluruh komponen baik dalam sistem, mekanisme, maupun pelaporannya.

Kelahiran PP No. 8 Tahun 2006 tentang Pelaporan Keuangan dan Kinerja Instansi Pemerintah, melahirkan sebuah harapan baru akan pentingnya manajemen kinerja yang tidak lagi mendasarkan penilaiannya pada kinerja keuangan saja tetapi juga kinerja organisasi secara umum termasuk kinerja manajemennya. Dalam kajian LAN tahun 2006 yang berjudul "Kajian Penyempurnaan SAKIP sesuai dengan Terbitnya Peraturan Pemerintah Nomor 8 Tahun 2006 tentang Pelaporan Keuangan dan Kinerja Instansi Pemerintah" memberikan beberapa rekomendasi penting terkait dengan komponenkomponen yang terkandung didalamnya, yaitu : (1) Perencanaan Stratejik; (2) Renstra KL - Renstra SKPD; (3) Perencanaan Kinerja yang meliputi : (a)Rencana Kerja Pemerintah (RKP) - Rencana Kerja Pemerintah Daerah (RKPD), (b) Rencana Kerja KL (Renja KL) Rencana Kerja SKPD (Renja SKPD), (c) Rencana Kerja dan Anggaran KL (RKA-KL) - Rencana Kerja dan Anggaran SKPD (RKA-SKPD), dan (d) P e netapan Kinerja; (4) Pengukurang Kinerja; dan (5) Pelaporan Akuntabilitas Kinerja (LAKIP).

Pada tahun 2009, Pemerintah melalui Menteri PPN/Kepala Bappenas mengeluarkan Permen PPN/Kepala Bappenas Nomor 5 Tahun 2009 tentang Pedoman Penyusunan Renstra-KL 2010-2014. Penyusunan Renstra-KL 2010-2014 adalah satu kegiatan yang berada dalam bingkai besar penyusunan dokumen perencanaan pembangunan nasional lima tahunan, yang kita kenal dengan Rencana Pembangunan Jangka Menengah Nasional (RPJMN) tahun 2010-2014. Sebagaimana tertuang di dalam Undang-undang Nomor 25 Tahun 2004 tentang Sistem Perencanaan Pembangunan Nasional, Menneg PPN/Kepala Bappenas mendapatkan mandat untuk menyiapkan rancangan awal RPJM Nasional sebagai penjabaran dari visi, misi, dan program Presiden terpilih.

Penjabaran visi, misi, dan program Presiden ke dalam dokumen RPJMN 2010-2014 tersebut tidak berdiri sendiri karena sesuai dengan 
ketentuan di dalam Peraturan Pemerintah Nomor 40 Tahun 2006 tentang Tata Cara Penyusunan Rencana Pembangunan Nasional, terdapat enam tahapan yang harus dilalui, yakni: (1) penyiapan Rancangan Awal RPJM Nasional; (2) penyiapan Rancangan Renstra-KL; (3) penyusunan Rancangan RPJM Nasional dengan menggunakan Rancangan Renstra-KL; (4) pelaksanaan Musrenbang Jangka Menengah Nasional; (5) penyusunan Rancangan Akhir RPJM Nasional; dan (6) penetapan RPJM Nasional. RPJMN yang telah ditetapkan melalui Peraturan Presiden selanjutnya dijadikan pedoman bagi penyusunan Renstra-KL; selain dalam kerangka tahunan, dijabarkan ke dalam Rencana Kerja Pemerintah (RKP).

Rancangan Renstra-KL adalah salah satu komponen terpenting dalam penyusunan RPJMN. Hal ini tercermin dalam Pasal 13 ayat (8) Peraturan Pemerintah Nomor 40 Tahun 2006, yakni bahwa Rancangan Renstra-KL digunakan sebagai bahan penyusunan Rancangan RPJMN. Dengan demikian, tidak bisa tidak harus ada konsistensi antara Renstra-KL dengan RPJMN s ehingga masing-masing Kementerian/Lembaga dapat bersinergi satu sama lain dan secara bersama-sama berkontribusi bagi pencapaian visi, misi, dan program Presiden dalam lima tahun mendatang. Penerbitan Pedoman Penyusunan Renstra-KL 2010-2014 adalah merupakan upaya kita untuk menjaga konsistensi tersebut.

Sebagai tindak lanjut atas PP No. 8 Tahun 2006 tentang Pelaporan Keuangan dan Kinerja Instansi
Pemerintah, PP No. 39 Tahun 2006 tentang Tata Cara Pengendalian dan Evaluasi Pelaksanaan Rencana Pembangunan, PP No. 40 Tahun 2006 tentang Tata Cara Penyusunan Rencana Pembangunan Nasional, PP No. 8 tahun 2008 tentang Tahapan Tata Cara, $\mathrm{P}$ e $\mathrm{n}$ y $\mathrm{u}$ s u $\mathrm{n}$ a $\mathrm{n}$, Pengendalian dan Evalua s i Pelaksanaan Rencana Pembangunan Daerah, Perpres No. 24 Tahun 2010 tentang Kedudukan, Tugas, dan Fungsi Kementerian Negara serta Susunan Organisasi, Tugas dan Fungsi Eselon I Kementerian, dan Instruksi Presiden Republik Indonesia Nomor 7 Tahun 1999 tentang Akuntabilitas Kinerja Instansi Pemerintah, Pemerintah melalui Kementerian PAN mengeluarkan Peraturan Menteri PAN dan RB No. 29 Tahun 2010 tentang Pedoman Penyusunan Penetapan Kinerja dan Pelaporan Akuntabilitas Kinerja Instansi Pemerintah.

Bentuk penetapan kinerja yang dimaksud berupa dokumen penetapan kinerja yang diharapkan setiap instansi pemerintah pusat dan daerah, menyusun penetapan kinerja instansi masing-masing. Berikut ini adalah pimpinan pada instansi Pemerintah dan Pemerintah Daerah yang diharapkan menyusun dokumen Penetapan Kinerja sebagai berikut :

a. Kementerian negara/lembaga menyusun penetapan kinerja $\mathrm{t} \mathrm{ing} \mathrm{k} \mathrm{a} \mathrm{t} \mathrm{k} \mathrm{e} \mathrm{m} \mathrm{e} \mathrm{n} \mathrm{t} \mathrm{e} \mathrm{r} \mathrm{i} \mathrm{a} \mathrm{n}$ negara/lembaga dan ditandatangani oleh menteri/pimpinan lembaga.

b. Unit organisasi eselon I menyusun penetapan kinerja tingkat unit organisasi setelah menerima dokumen pelaksanaan anggaran dan ditandatangani oleh 
menteri/pimpinan lembaga dan pimpinan unit organisasi.

c. Satuan kerja dan unit kerja eselon II menyusun penetapan kinerja setelah menerima dokumen pelaksanaan anggaran dan ditandatangani oleh pimpinan unit organisasi dan pimpinan satuan kerja.

d. SKPD dan unit kerja mandiri pemerintah provinsi/ kabupaten/kota menyusun penetapan kinerja setelah menerima dokumen pelaksanaan anggaran dan ditandatangani oleh gubernur/bupati/walikota dan pimpinan SKPD/unit kerja

Esensi penetapan kinerja ini suatu pernyataan kinerja/kesepakatan kinerja/ perjanjian kinerja antara atasan dan bawahan untuk mewujudkan target kinerja tertentu berdasarkan pada sumber daya yang dimiliki oleh instansi. Integrasi sistem perencanaan, penganggaran dan manajemen dalam konteks kebijakan di Indonesia dapat digambarkan berikut ini:

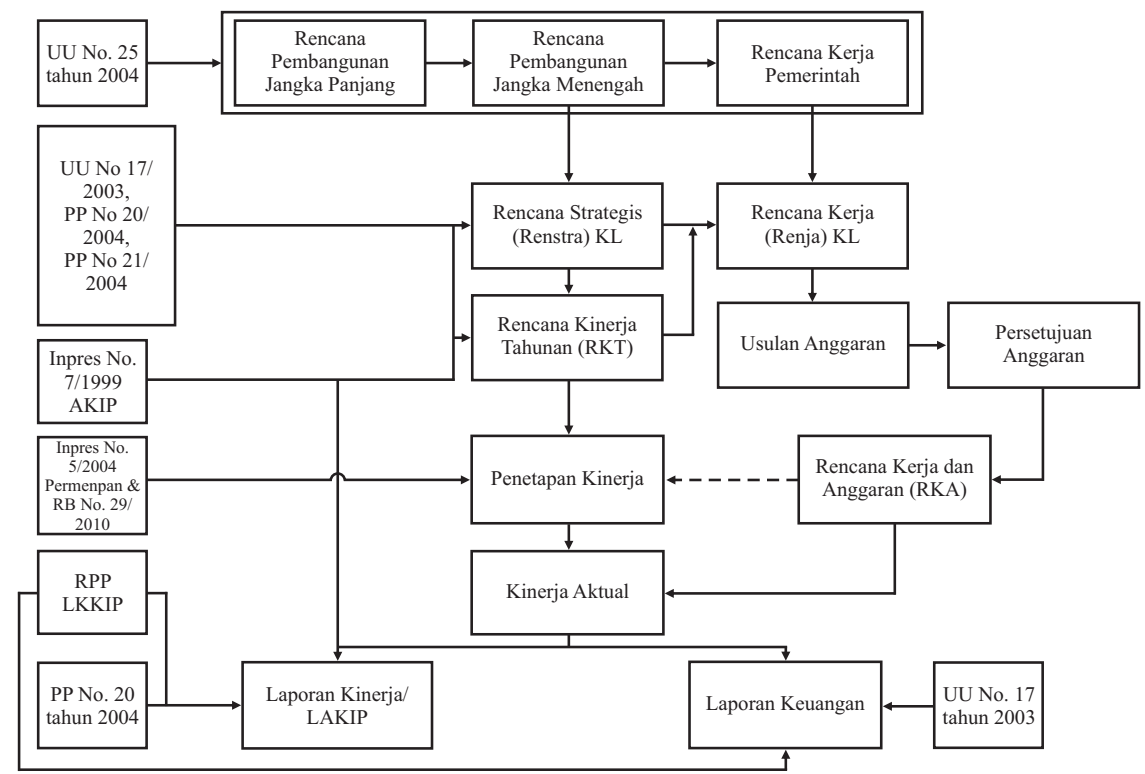

Sumber: Modul SAKIP Kepmenpan, dikutip dari Bambang Sancoko, dkk (2008), direvisi.

Gambar 1. Keterkaitan SAKIP, Perencanaan dan Penganggaran

\section{Konsep Renstra}

Penerapan model perencanaan stratejik sudah mulai diterapkan pada sektor publik di Indonesia sejak tahun 1999 melalui Sistem Akuntabilitas Kinerja Instansi Pemerintah. Sejak tahun tersebut model perencanaan strategis berkembang terus sejalan dengan berbagai perubahan dalam sistem perencanaan nasional.
Pada level pemerintah pusat, perkembangan terakhir implementasi perencanaan strategis pada sektor publik adalah dengan diterbitkannya Pedoman Penyusunan Rencana Strategis Kementerian/Lembaga (Renstra KL) 2010 - 2014 melalui Peraturan Menteri Negara Perencanaan Pembangunan Nasional/Kepala Badan Perencanaan Pembangunan Nasional 
Nomor: 5 Tahun 2009. Dalam pedoman dimaksud, Rencana Strategis Kementerian/Lembaga didefinisikan sebagai dokumen perencanaan Kementerian/Lembaga untuk periode lima tahun, yaknis tahun 2010 sampai dengan 2014 yang merupakan penjabaran dari RPJMN 2010-2014.

Secara hirarki, dalam sistem perencanaan nasional, RPJMN merupakan pejabaran dari visi, misi, dan program Presiden terpilih, yang memuat sasaran dan strategi pembangunan nasional selama 5 tahun masa pemerintahan. RPJMN, sebagai amanat pembangunan jangka menengah, kemudian dijabarkan ke dalam dokumen perencanaan yang menjadi acuan kementerian/lembaga dalam mendukung pencapaian program prioritas RPJMN, yang disebut dengan Dokumen Rencana Strategis (Renstra-KL).

Rencana Strategis K/L memuat visi, misi, tujuan, strategi, kebijakan serta program dan kegiatan kementerian/lembaga sesuai dengan tugas pokok dan fungsinya, yang disusun dengan berpedoman pada RPJMN. Dokumen ini juga memuat keluaran maupun sumberdaya yang sifatnya masih indikatif. Secara singkat komponen Renstra tersebut dapat dijelaskan sebagai berikut : pertama, visi, dalam dokumen rencana strategis, didefinisikan sebagai rumusan umum mengenai keadaan yang diinginkan pada akhir periode perencanaan; kedua, misi, didefinisikan sebagai rumusan umum mengenai upaya-upaya yang akan dilaksanakan untuk mewujudkan visi.
Model Renstra yang dikembangkan oleh pemerintah juga mengandung tujuan dan sasaran, tetapi dalam pedoman Penyusunan Rencana Strategis KL tidak memberikan definisi mengenai tujuan dan sasaran. Selain itu, Renstra juga harus memuat target dari sasaran strategi, yang merupakan hasil yang ingin dicapai oleh sasaran strategis dalam kurun waktu tertentu.

Renstra K/L juga memuat arah kebijakan dan strategi. Kebijakan adalah arah/tindakan yang diambiloleh pemerintah pusat/daerah untuk mencapai tujuan. Sedangkan strategi adalah langkah-langkah berisikan program-program indikatif untuk mewujudkan visi dan misi. Secara lebih detail disebutkan dalam pedoman bahwa arah kebijakan dan strategi melingkup langkah-langkah yang berupa program-program indikatif untuk memecahkan permasalahan yang penting dan mendesak untuk segera dilaksanakan dalam kurun waktu tertentu (jangka menengah) serta memiliki dampak besar terhadap pencapaian visi, misi, tujuan dan sasaran strategis. Sebagai bagian dari sistem perencanaan nasional, maka program-program juga harus mencakup kegiatan yang menjadi prioritas dalam RPJMN sesuai dengan bidang terkait.

Program adalah instrumen kebijakan yang berisi kegiatankegiatan yang dilaksanakan oleh $\mathrm{K} / \mathrm{L}$ untuk mencapai sasaran da tujuan serta memperoleh alokasi anggaran dan/atau kegiatan masyarakat yang dikoordinasikan oleh $\mathrm{K} / \mathrm{L}$. sedangkan kegiatan didefinisikan sebagai bagian dari program yang dilaksanakan oleh 
satuan kerja setingkat eselon II yang terdiri dari sekumpulan tindakan oengerahan sumber daya baik yang berupa personil (sumber daya manusia), barang modal termasuk peralatan dan teknologi, dana, dan/atau kombinasi dari beberapa atau kesemuan jenis sumberdaya tersebut sebagai masukan (input) untuk menghasilkan keluaran (output) dalam bentuk barang/jasa. Baik program maupun kegiatan harus dilengkapi dengan Indikator Kinerja, yang ditetapkan secara spesifik untuk mengukur pencapaian kinerja berkaitan dengan informasi kinerja (outputs, outcomes dan impacts).

\section{Kinerja dan Manajemen Kinerja}

Bates, RA dan Holton E.F (1995) mengemukakan bahwa kinerja merupakan suatu konstruksi atau konsepsi yang multi dimensional dimana pengukuran mengenai hal tersebut sangat bervariasi tergantung pada jenis dan faktor-faktor yang ada. Bates dan Holton juga mengemukakan pentingnya menentukan tujuan pengukuran yakni untuk menilai hasil kinerja atau perilaku seseorang.

Pandangan yang lebih komprehensif dari kinerja dikemukakan oleh Brumbach (1988) yang memadukan definisi kinerja a $\mathrm{n} \mathrm{t}$ a r a p r i l a k u d a n kemanfaatan/outcomes. Menurut Brumbach, kinerja diartikan sebagai perpaduan antara prilaku dan manfaat. Prilaku berasal dari pelaku dan perpindahan kinerja dari abstraksi kepada tindakan. Kinerja tidak hanya meliputi instrumen-instrumen untuk hasil dan prilaku-prilaku tetapi juga manfaat pada mereka - produk mental dan fisik yang berusaha untuk diterapkan dalam tugas-tugas - dan dapat dinilai sebagai bagian dari hasilhasil.

Sebagian besar ahli manajemen menyatakan bahwa manajemen kinerja dianggap sebagai proses manajemen yang menghasilkan outcome melalui perencanaan SDM, pengembangan, penilaian dan proses pemberian penghargaan sehingga pencapaian target kinerja yang ditetapkan organisasi (LAN, 2009; 2010).

Amstrong (1994) tampaknya tidak menolak definisi tersebut, dimana dia menyatakan bahwa manajemen kinerja berkenaan dengan proses kerja, manajemen, pengembangan dan imbalan yang saling berhubungan. Menurutnya, manajemen kinerja dapat menjadi suatu kekuatan penggabung yang amat kuat dalam pengembangan manajemen sumber daya manusia dalam lingkup organisasi. Sedangkan fungsi manajemen kinerja sebagai proses yang terintegrasi disajikan pada gambar di bawah. 


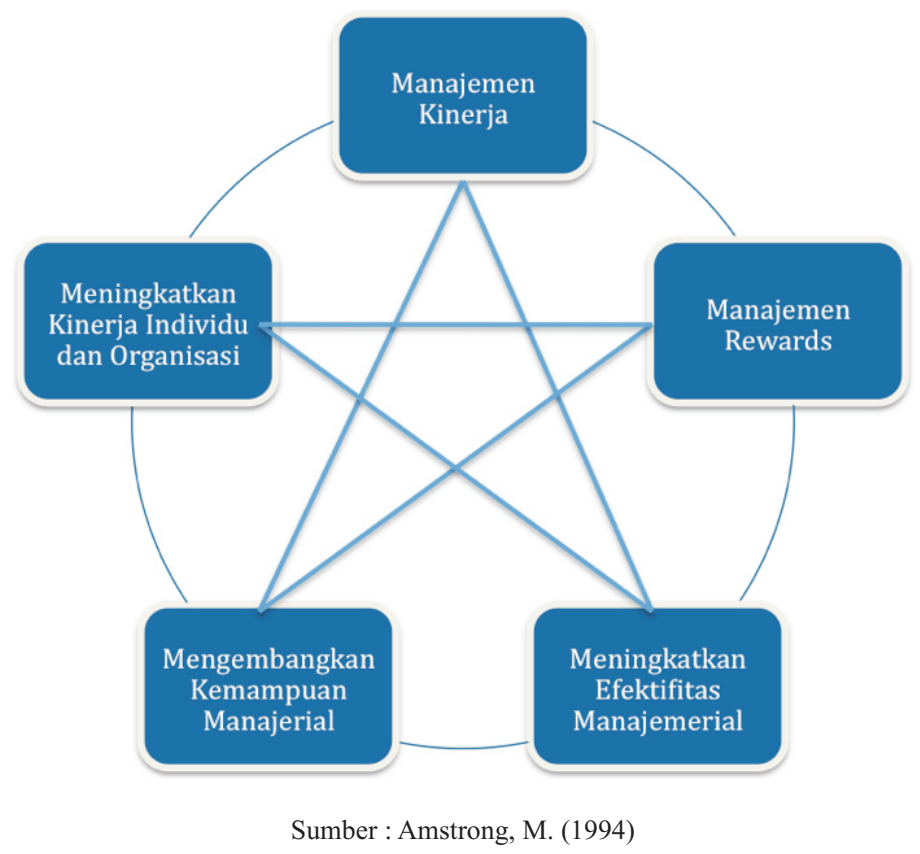

Gambar 2. Manajemen Kinerja Sebagai Pendorong Integrasi

Manajemen kinerja yang efektif memberikan dasar bagi usaha mengkomunikasikan misi, nilai-nilai dan sasaran organisasi kepada seluruh anggota organisasi. Peranan manajemen kinerja dalam mendukung pencapaian strategi organisasi adalah dengan suatu cara mengintegrasikan sasaran ke bawah, ke atas dan ke samping di seluruh tubuh organisasi. Pada hakekatnya manajemen kinerja lebih merupakan suatu manajemen berdasarkan kesepakatan ataupun kontrak kinerja daripada merupakan suatu manajemen berdasarkan komando.

Berbagai definisi tentang manajemen kinerja di atas, tampaknya juga mempengaruhi kebijakan manajemen kinerja di Indonesia. Dalam sebuah kajian yang dilakukan Bappenas (2006) misalnya, manajemen kinerja didefinisikan mengelola untuk hasil (result oriented) merupakan penggunaan sumberdaya dan informasi untuk mencapai tujuan organisasi melalui progress yang terukur (performance measurement). Konsep ini kemudian dikembangkan di dalam Pedoman Manajemen Kinerja Kementerian Negara PPN/Bappenas dimana manajemen kinerja didefinisikan agak berbeda yakni sebagai suatu proses atau seperangkat proses untuk menciptakan pemahaman bersama mengenai apa yang harus dicapai, bagaimana hal itu bisa dicapai, serta bagaimana mengelola orang dengan cara yang dapat meningkatkan kemungkinan tercapainya tujuan.

\section{BSC sebagai Management Tools}

Dari berbagai konsep manajemen kinerja di Indonesia, sekalipun telah mengadopsi konsep 
Balance Scorecard $(\mathrm{BSC})^{2}$, namun dalam prakteknya, konsep BSC tidak diterapkan secara utuh. Untuk itu, dalam kerangka konsep ini akan sedikit dijelaskan tentang apa dan bagaimana BSC bekerja.

Penerapan BSC pada mulanya banyak dilakukan pada organisasi swasta yang memiliki orientasi keuntungan. Tetapi kemudian dengan modifikasi-modifikasi tertentu, BSC mulai diterapkan disektor publik (pemerintah dan organisasi non profit). Bahkan beberapa departemen/lembaga pemerintah sudah mulai menerapkan BSC. Modifikasi yang banyak dilakukan adalah dengan menempatkan pemangku kepentingan sebagai unsur yang paling atas dalam rantai keterkaitan perspektif, sementara perspektif keuangan serta inovasi dan pembelajaran menjadi unsur yang paling bawah. Tidak tertutup kemungkinan dilakukan modifikasi-modifikasi lainnya. Oleh karena itu, sebelum pendekatan ini digunakan, sebaiknya disepakati terlebih dahulu perspektif-perspektif yang akan digunakan. Untuk keperluan pedoman ini, akan digunakan perspektif stakeholders (pemangku kepentingan), proses internal, inovasi dan pembelajaran serta keuangan.

Perspektif Pemangku Kepentingan (stakeholders). Organisasi pemerintah pada dasarnya dibentuk untuk memberikan pelayanan kepada masyarakat baik secara langsung maupun tidak langsung, atau kepada organisasi instansi pemerintah lainnya, dengan pengawasan yang ketat dari unsur-unsur masyarakat, legislatif, serta institusi pengawasan untuk menjamin akuntabilitasnya. Perspektif ini menuntut organisasi mengetahui betul siapa yang menjadi pemangku kepentingannya. Perspekt if stakeholders memfokuskan kepada upaya yang dilakukan oleh organisasi instansi pemerintah dengan segala sumber daya yang dimilikinya (atau dipercayakan kepadanya) sehingga dapat memberikan kepuasan kepada seluruh stakeholder. Indikator yang dikembangkan biasanya terkait dengan sejauhmana organisasi instansi pemerintah telah mampu memenuhi kepuasan/harapan stakeholder, seperti kualitas produk/jasa, hubungan dengan pelanggan, tingkat kepuasan pelanggan, citra dan reputasi organisasi.

\section{Perspektif Proses Bisnis} Internal. Perspektif ini merupakan serangkaian aktivitas perbaikan dan peningkatan proses pengelolaan sumberdaya organisasi sedemikian sehingga proses dapat digunakan untuk memenuhi keinginan pelanggan atau stakeholder. Perspektif ini memfokuskan pada upaya pemanfaatan sumber-sumber secara optimal, perbaikan kualitas pelayanan, peningkatan fasilitas, ketersediaan produk-produk pelayananan, dan lainnya. Indikator yang digunakan untuk menilai kemajuan pencapaian tujuan antara lain melalui: kualitas proses, kecepatan, ketepatan, tingkat

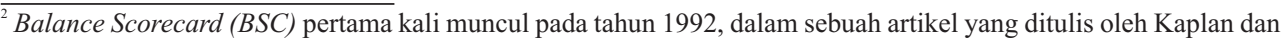
Norton di majalah Harvard Business Review, Edisi Januari-Februari 1992. Selanjutnya BSC telah berkembang dengan pesat, dan pada tahun 1996 Kaplan dan Norton merevisi BSC yang telah mereka bangun sejak 1992 tersebut. Revisi BSC yang baru ini memunculkan stategy map (peta strateji).
} 
kegagalan produk/jasa, dan lainnya.

Perspektif Inovasi dan Pembelajaran. Perspektif ini memfokuskan pada bagaimana organisasi dapat mempertahankan dan meningkatkan kemampuannya dalam menghadapi tantangan perubahan. Pespektif ini memfokuskan pada upaya yang dilakukan organisasi instansi pemerintah sehingga mampu secara berkelanjutan meningkatkan kapasitasnya untuk kepentingan memenuhi harapan stakeholders melalui peningkatan kompetensi karyawan, daya dukung teknologi, budaya organisasi, kepemimpinan, motivasi dan penghargaan. Indikator yang dikembangkan untuk melihat kemajuan pencapaian antara lain melalui : kepuasan pegawai, kapasitas pegawai, kualitas kepemimpinan, kinerja pegawai, dan lainnya.
Perspektif Keuangan. Perspektif ini memfokuskan pada upaya organisasi untuk tetap menjaga sumber-sumber keuangan bagi pembiayaan kegiatan dalam rangka mewujudkan visinya. Namun demikian, organisasi juga dituntut untuk melakukan pengelolaan keuangannya secara akuntabel dengan memperlihatkan upaya untuk terus memenuhi, mempertahankan dan meningkatkan kepuasan para pemangku kepentingan sesuai dengan anggaran yang dimilikinya. Indikator yang digunakan untuk melihat kemajuan perspektif ini antara lain adalah: efektivitas, efisiensi, kepatuhan terhadap peraturan perundangundangan dalam pengelolaan keuangan, hasil penilaian terhadap laporan keuangan oleh BPK, dan lainnya.

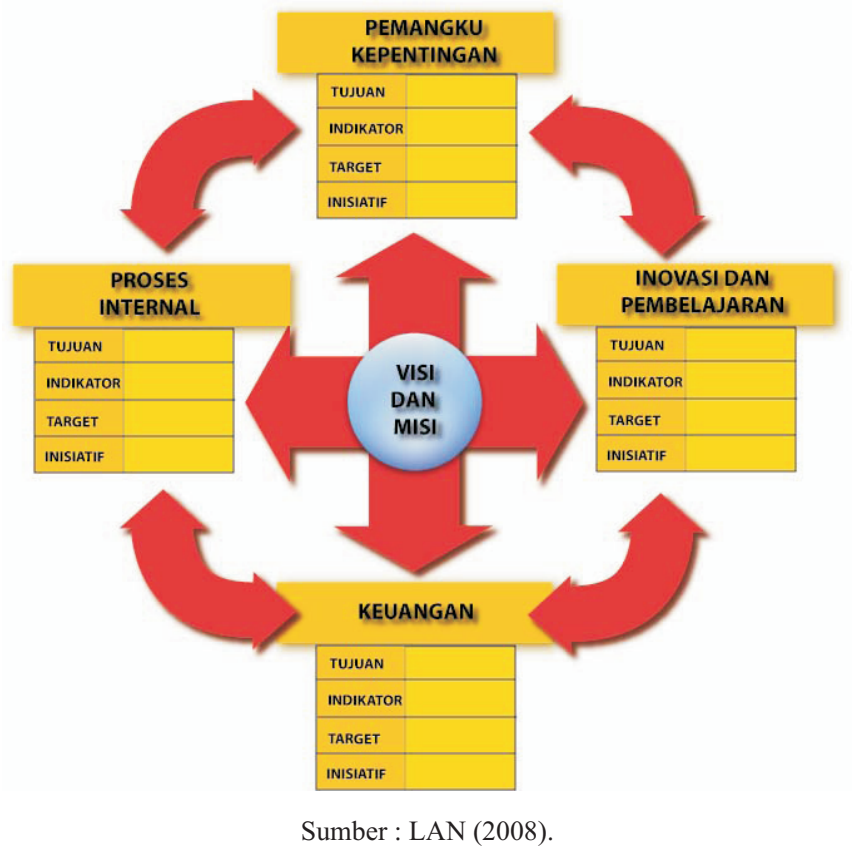

Gambar 3. Model Balance Scorecard 
Agar kemajuan yang telah diperoleh dapat diketahui dari waktu kewaktu, maka dikembangkan semacam alat ukur yang disebut dengan kartu skor (scorecard), yang memuat indikator-indikator kunci serta target dan nilai capaiannya. Keseimbangan (balanced) nilai yang diperoleh akan menunjukkan sinergi keseluruhan perspektif, sekaligus menunjukkan bagaimana organisasi mengelola kinerjanya dengan baik.

\section{INTEGRASI SPAMK DI BANK I N D O N E S I A : S E B U A H ANALISIS}

Gagasan untuk melakukan perubahan di Bank Indonesia sudah dimulai sejak tahun 1999 sebagai jawaban atas lahirnya UU No. 23/1999 tentang Bank Indonesia yang kemudian diubah dengan UU No. 6 Tahun 2009. Dari sinilah awal babak baru sejarah Bank Indonesia sebagai Bank Sentral yang independen. Undang-undang ini memberikan status dan kedudukan sebagai suatu lembaga negara yang independen dalam melaksanakan tugas dan wewenangnya, bebas dari campur tangan Pemerintah dan/atau pihak lain, kecuali untuk hal-hal yang secara tegas diatur dalam undang-undang ini. Bank Indonesia mempunyai otonomi penuh dalam merumuskan dan melaksanakan setiap tugas dan wewenangnya sebagaimana ditentukan dalam undang-undang tersebut. Pihak luar tidak dibenarkan mencampuri pelaksanaan tugas Bank Indonesia, dan Bank Indonesia juga berkewajiban untuk menolak atau mengabaikan intervensi dalam bentuk apapun dari pihak manapun juga. Status dan kedudukan yang khusus tersebut diperlukan agar Bank Indonesia dapat melaksanakan peran dan fungsinya sebagai otoritas moneter secara lebih efektif dan efisien.

Agar dalam menjalankan peran dan fungsinya sebagai pemegang otoritas moneter, lebih terarah dan sistematis diperlukan arah kebijakan strategis Bank Indonesia yang dituangkan di dalam misi, visi, nilainilai strategis dan sasaran strategis sebagai berikut :

Misi Bank Indonesia adalah "Mencapai dan memelihara kestabilan nilai rupiah melalui pemeliharaan kestabilan moneter dan pengembangan stabilitas sistem keuangan untuk pembangunan nasional jangka panjang yang berkesinambungan". Sedangkan visi yang diemban Bank Indonesia adalah "Menjadi lembaga bank sentral yang dapat dipercaya (kredibel) secara nasional maupun internasional melalui penguatan nilai-nilai strategis yang dimiliki serta pencapaian inflasi yang rendah dan stabil". Dalam pencapaian misi dan misi tersebut, setiap pegawai memiliki nilai-nilai perubahan yang digunakan sebagai dasar dalam mendorong kinerja bersama yang disingkat KITA-Kompak, yang dijabarkan ke dalam nilai-nilai dasar: kompetensi, integritas, transparansi, akuntabilitas, dan kebersamaan.

Sedangkan sasaran strategis yang setiap jangka menengah panjang akan dicapai Bank Indonesia adalah sebagai berikut: (1) Terpeliharanya kestabilan moneter, (2) Terpeliharanya stabilitas sistem keuangan, (3) Terpeliharanya kondisi keuangan Bank Indonesia yang sehat dan akuntabel, (4) Meningkatkan 
efektifitas dan efisiensi manajemen moneter, (5) Memelihara stabilitas sistem keuangan, melalui : (a) efektifitas pengaturan dan pengawasan bank, surveillance sektor keuangan, dan manajemen krisis serta (b) mendorong fungsi intermediasi. Selain itu, sasaran strategis berikutnya adalah (6) Memelihara keamanan dan efisiensi sistem pembayaran, (7) Meningkatkan kapabilitas organisasi, SDM dan sistem informasi, (8) Memperkuat institusi melalui good governance, efektivitas komunikasi dan kerangka hukum, dan (9) Mengoptimalkan pencapaian dan manfaat inisiatif Bank Indonesia.

Dalam kapasitasnya sebagai bank sentral, Bank Indonesia mempunyai satu tujuan tunggal, yaitu mencapai dan memelihara kestabilan nilai rupiah. Kestabilan nilai rupiah ini mengandung dua aspek, yaitu kestabilan nilai mata uang terhadap barang dan jasa, serta kestabilan terhadap mata uang negara lain.

Aspek pertama tercermin pada perkembangan laju inflasi, sementara aspek kedua tercermin pada perkembangan nilai tukar rupiah terhadap mata uang negara lain. Perumusan tujuan tunggal ini dimaksudkan untuk memperjelas sasaran yang harus dicapai Bank Indonesia serta batas-batas tanggung jawabnya. Dengan demikian, tercapai atau tidaknya tujuan Bank Indonesia ini kelak akan dapat diukur dengan mudah.

Untuk mencapai tujuan tersebut Bank Indonesia didukung oleh tiga pilar yang merupakan tiga bidang tugasnya (pilar). Ketiga bidang tugas tersebut perlu diintegrasi agar tujuan mencapai dan memelihara kestabilan nilai rupiah dapat dicapai secara efektif dan efisien: pertama, menetapkan dan melaksanakan kebijakan moneter, kedua, mengatur dan menjaga kelancaran sistem pembayaran dan ketiga, mengatur dan mengawasi bank.

Untuk mencapai tujuan organisasi dengan tiga pilar tersebut tentu bukan hal mudah. Dibutuhkan perubahan arah strategis organisasi sesuai dengan berbagai tuntutan stakeholders yang terus berubah. Karena hal inilah Sistem Perencanaan, Anggaran dan Manajemen Kinerja (SPAMK) Bank Indonesia lahir sebagai sistem manajemen kinerja yang terintegrasi dengan sistem perencanaan dan penganggaran. Sistem ini lahir karena dilatarbelakangi oleh kekurangmampuan sistem lama beradaptasi dengan tuntutan lingkungan strategis yang makin cepat. Alasan ini bisa dipahami karena selama ini sistem lama memiliki berbagai keterbatasan antara lain : (1) sistem yg lama sudah out of date, (2) sistem lama tidak mampu mengakomodasi tuntutan stakeholders eksternal dan internal, (3) sistem lama tidak mempunyai lingkage antara misi dan visi organisasi dengan sasaran satuan kerja, (4) sistem lama kurang mampu menterjemahkan keinginan top level of management dan menurunkannya ke dalam sasran strategic satuan kerja, (5) sistem lama kurang dapat mempertimbangkan kebutuhan kuantitas dan kualitas SDM, (6) sistem lama kurang dikaitkan dengan proses budgeting dan performance management. Hal ini tidak hanya dialami oleh BI saja, namun di sebagian besar organisasi 
pemerintahan juga mengalami. Karena itu konsep penerapan SAKIP yang tidak efektif juga disebabkan karena berbagai persoalan diatas.

Dalam sejarah perjalanan pengelolaan kinerja $\mathrm{BI}$ terlihat bahwa beberapa kerangka pemikiran berbeda telah diterapkan BI sejak era 1980-an. Pada pertengahan tahun 1980-an misalnya, kerangka Management by Objectives (MBO) diterapkan. Tetapi dalam penerapannya muncul pemahaman bahwa pengelolaan kinerja berbasis MBO terlalu menekankan pada hasil akhir sehingga kurang menghargai proses atau aktifitas yang diperlukan untuk pencapaiannya.

Selanjutnya pada tahun 1990 -an, diterapkan konsep Program Kerja
Strategis (PKS), dimana penilaian kinerja ditekankan pada kedisiplinan dari satuan kerja dalam melaksanakan aktifitas yang telah disetujui. Dengan dilaksanakannya aktifitas program kerja tersebut dengan baik, dipercaya hasil akhir akan tercapai. Program PKS ini dapat menutupi kelemahan MBO, tetapi disisi lain juga dapat menciptakan kelemahan baru yang justru dapat ditangani $\mathrm{MBO}$, yaitu penilaian yang hanya berdasarkan program kerja atau aktifitas semata yang menciptakan paradigma bahwa hasil akhir kurang penting.

Setidaknya, secara periodik, perkembangan sistem manajemen kinerja di Bank Indonesia dapat dijelaskan dalam tiga fase perkembangan, sebagaimana terihat pada Gambar 4 di bawah.
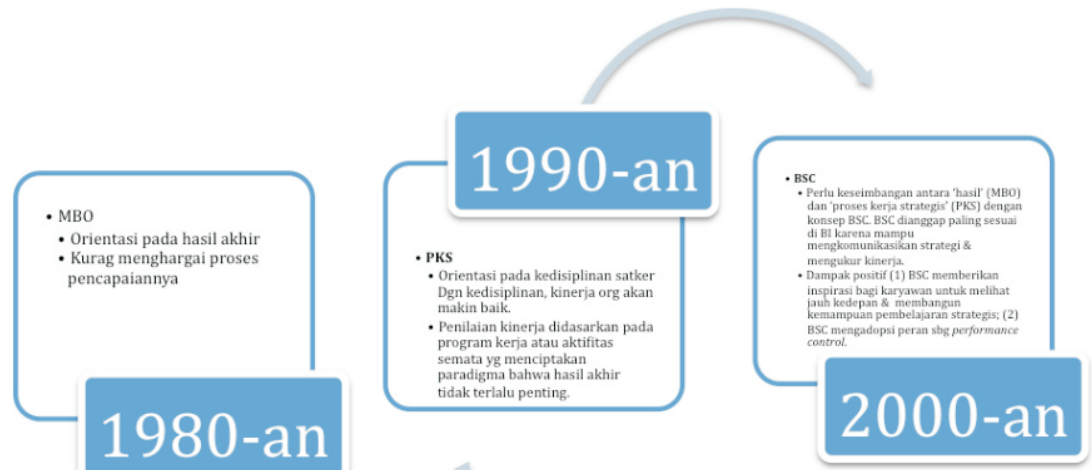

Sumber: Aulia Pohan dan Tim SPAMK (2006). Diolah.

Gambar 4. Sejarah Penerapan Sistem Manajemen Kinerja di Bank Indonesia

Terlepas dari kelebihan dan kekurangan konsep-konsep yang pernah diterapkan sebelumnya, perjalanan pengelolaan kinerja $\mathrm{BI}$ $\mathrm{sec}$ a r a bert a h a $\mathrm{tel}$ a h memprakondisikan pimpinan dan karyawan BI untuk menuju organisasi berbasis kinerja. Akhirnya, untuk menciptakan keseimbangan antara "hasil" (yang ditekankan oleh konsep MBO) dan proses kerja yang ditekankan oleh konsep PKS), Balance 
Scorecard dipilih sebagai suatu sistem yang paling sesuai untuk diterapkan di Bank Indonesia karena dapat menyeimbangkan antara hasil dan proses kerja.

Dalam perspektif teoritis, BSC memiliki dua tujuan untuk mengkomunikasikan strategi dan untuk mengukur kinerja. Pertama, dalam mengkomunikasikan strategi, BSC memberikan inspirasi kepada karyawan untuk melihat jauh ke depan, dan membangun kemampuan pembelajaran strategis. Kedua, BSC mengadopsi peran sebagai performance control tool. Scorecards dari ukuran dan target, dengan didukung oleh "dashboard system", dibangun untuk mendukung sasaran strategis dan menjaga satuan kerja dan segenap karyawan agar tetap fokus pada pelaksanaan strategi berdasarkan prioritas.

Dari dua tujuan tersebut, BSC mempunyai tiga rancangan komponen yaitu sebagai strategic vision, management tool, dan communication tool. Untuk itu perlu dibangun peta strategi yang menghubungkan sasaran strategis dan harapan para stakeholders eksternal BI, khususnya, masyarakat, pemerintah, kalangan perbankan dan DPR, dengan proses internal BI, teknologi, dan kemampuan sumberdaya manusia.

Bagaimana BI mengadaptasi BSC? Sebagaimana diketahui proses perubahan penerapan manajemen kinerja di BI dilakukan secara serius dengan dukungan komitmen pimpinan dan seluruh karyawan BI. Karena itu, ketiga proses perubahan tersebut dikelola oleh sebuah Tim dibawah program Transformasi Bank Indonesia, maka dukungan internal BI mulai dari top manajemen hingga karyawan memberikan dukungan positif.

Atas dasar kesadaran ingin membangun Bank Sentral yang lebih baik, sekaligus untuk menjaga momentum Bank Indonesia sebagai lembaga independen yang ditandai oleh lahirnya UU No. 23/1999 tentang Bank Indonesia yang kemudian diubah dengan UU No. 6 Tahun 2009, sejak itulah kemudian lahir gagasan transformasi. Pada tahun 1999 dibentuk Tim Transformasi dengan Keputusan Gubernur Bank Indonesia -SK No. 3/5/KEP.GBI/INTERN/2001 dan SK No. 4/4/KEP.GBI/INTERN/ 2001. Selain itu, respon Dewan Gubernur juga terlihat dari dilakukannya Board Retreat II pada bulan April tahun 2000. Forum ini kemudian membahas perumusan konsep Bank Indonesia yang baru dengan berbagai penyesuaian arah strategis organisasi dengan tuntutan yang makin berubah.

Berdasarkan berbagai arahan dewan Gubernur tersebut, disepakati tiga tahapan penting dalam program transformasi Bank Indonesia sebagai berikut : (1) diperlukan Diagnostic Study; (2) Disain dan pengembangan konsep termasuk persiapan i m p le me n t a s in y a; d a n (3) implementasinya.

\section{Diagnostic Study}

Diagnostic Study bertujuan untuk menganalisa kondisi Bank Indonesia secara komprehensif dan untuk menentukan arah, strategi, dan 
rencana kegiatan. Metode yang digunakan pun beragam, mulai dari interview dengan kalangan stakeholders internal maupun eksternal, Focus Group Discussion dengan mengundang para pimpinan unit kerja tertentu, pemetaan proses kerja dan analisa alokasi SDM. Melalui serangkaian proses kerja tersebut dihasilkan beberapa rekomndasi mengenai arah strategis Bank Indonesia yang baru (new strategic direction) yang meliputi misi, visi, nilai-nilai strategis organisasi serta sasaran strategis.
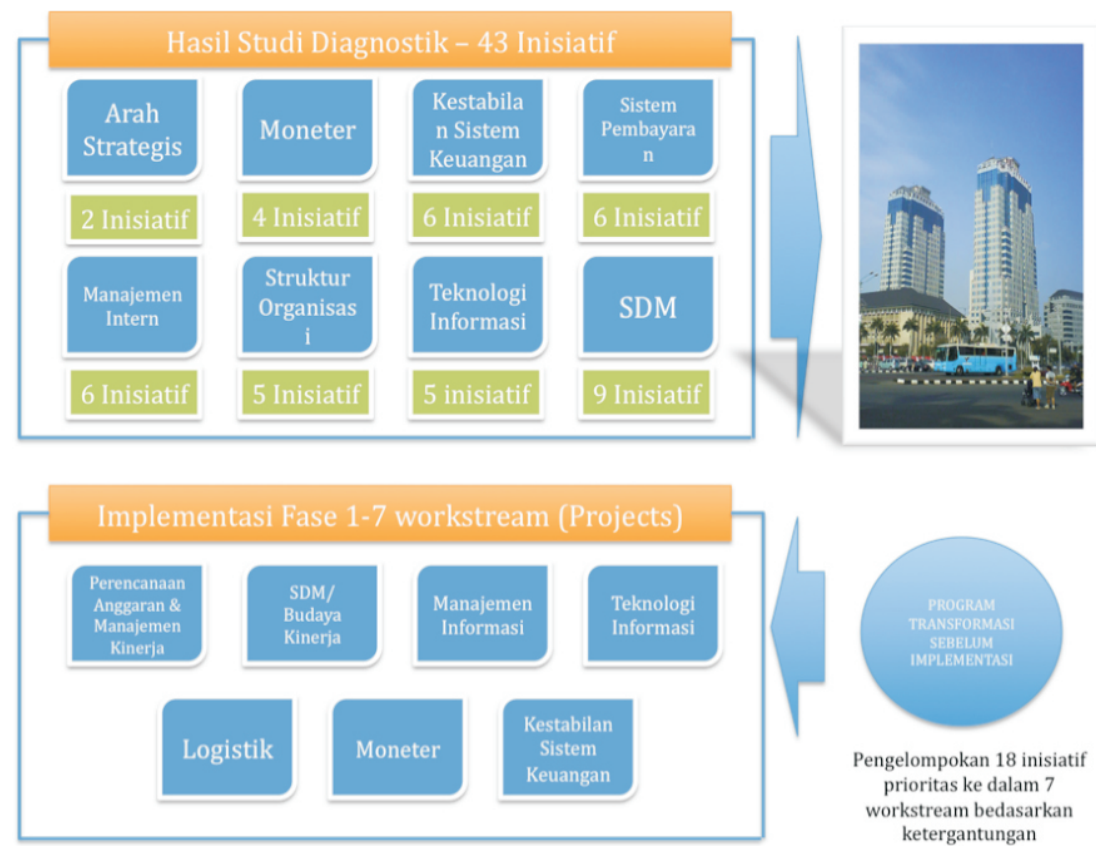

Sumber : Aulia Pohan dan Tim SPAMK (2006). Diolah

Gambar 5. Hasil Studi Diagnostik: Program Transformasi Bank Indonesia

Fase ini diharapkan mampu merumuskan berbagai insiatif strategis baik dari stakeholder internal maupun eksternal. Kasus di BI, diagnostic study mampu melahirkan 43 inisiatif srategis, yang kemudian dalam Board Retread III dibuat prioritas inisiatif strategis menjadi 18 langkah strategis. Selanjutnya 18 inisiatif strategis tersebut dikelompokkan ke dalam tujuh workstream yang meliputi : (1) Perencanaan, Anggaran dan Manajemen Kinerja, (2) Logistik,
(3) Sumberdaya Manusia termasuk di dalamnya Budaya Kinerja, (4) Teknologi Informasi, (5) Manajemen Informasi, (6) Moneter, (7) Kestabilan Sistem Keuangan (lihat Gambar 5 di atas).

Untuk menindaklanjuti hasil studi diagnosis tersebut, dibuatlah beberapa langkah alternatif dalam metode pelaksanaannya : pertama, menyusun program penyempurnaan yang dilaksanakan oleh unit terkait; 
kedua, pelaksanaan dilakukan secara langsung oleh satuan kerja yang mengelola organisasi dan SDM; ketiga, pembentukan unit khusus untuk melaksanakan dan mengkoordinir keseluruhan proses Program Transformasi Bank Indonesia.

Dalam perkembangannya, alternatif ke-3 yang dijadikan alternatif pilihan untuk memastikan adanya tim yang berkomitmen dan fokus, yakni dengan dibentuknya satuan kerja baru yang kemudian disebut dengan Unit Khusus Program Transformasi (UKPT), yang lahir sejak 1 September 2011.

Untuk proses implementasi juga terdapat beberapa pilihan, namun yang ditetapkan sebagai pilihan adalah steady scale of effort dan continuous broad focus dimana implementasi program dilakukan secara terus menerus tanpa mengganggu kegiatan operasional Bank Indonesia. Pendekatan tersebut dipilih dengan pertimbangan dapat menciptakan keseimbangan antara pelaksanaan program dan pelaksanaan tugas reguler Bank Indonesia. Dengan demikian, pelaksanaan program dapat diprioritaskan di berbagai area, tetapi bila dibandingkan dengan pendekatan big bang, pendekatan ini memiliki resiko kehilangan momentum ataupun ketidakjelasan program secara keseluruhan.

Disain, Pengembangan Konsep dan Implementasinya

Tahapan kedua dan ketiga diformulasikan ke dalam siklus Sistem Perencanaan, Penganggaran dan Manajemen Kinerja (dapat dilihat dalam Gambar 6 di bawah). Siklus SPAMK dimulai dengan top-down approach dimana Dewan Gubernur menentukan arah strategis dan indikator kinerja utama (IKU) dalam Board Retreat. Arah strategis ini lalu digunakan untuk membangun proyeksi keuangan dan acuan anggaran BI. Kemudian, arah strategis dan acuan anggaran tersebut dikomunikasikan ke semua satuan kerja melalui Forum Strategis (Forstra). Forstra inilah yang oleh Kaplan dan Norton (1996) dianggap sebaga i forum mengkomunikasikan untuk mengkomunikasikan sasaran stratejik hingga level pimpinan satuan kerja. Arahan di dalam Forstra selanjutnya digunakan oleh masing-masing satuan kerja untuk membuat sasaran strategis, IKU dan budget mereka, yang kemudian akan dinegosiasikan dan disetujui oleh anggota Dewan Gubernur yang bertanggungjawab atas satuan kerja. 

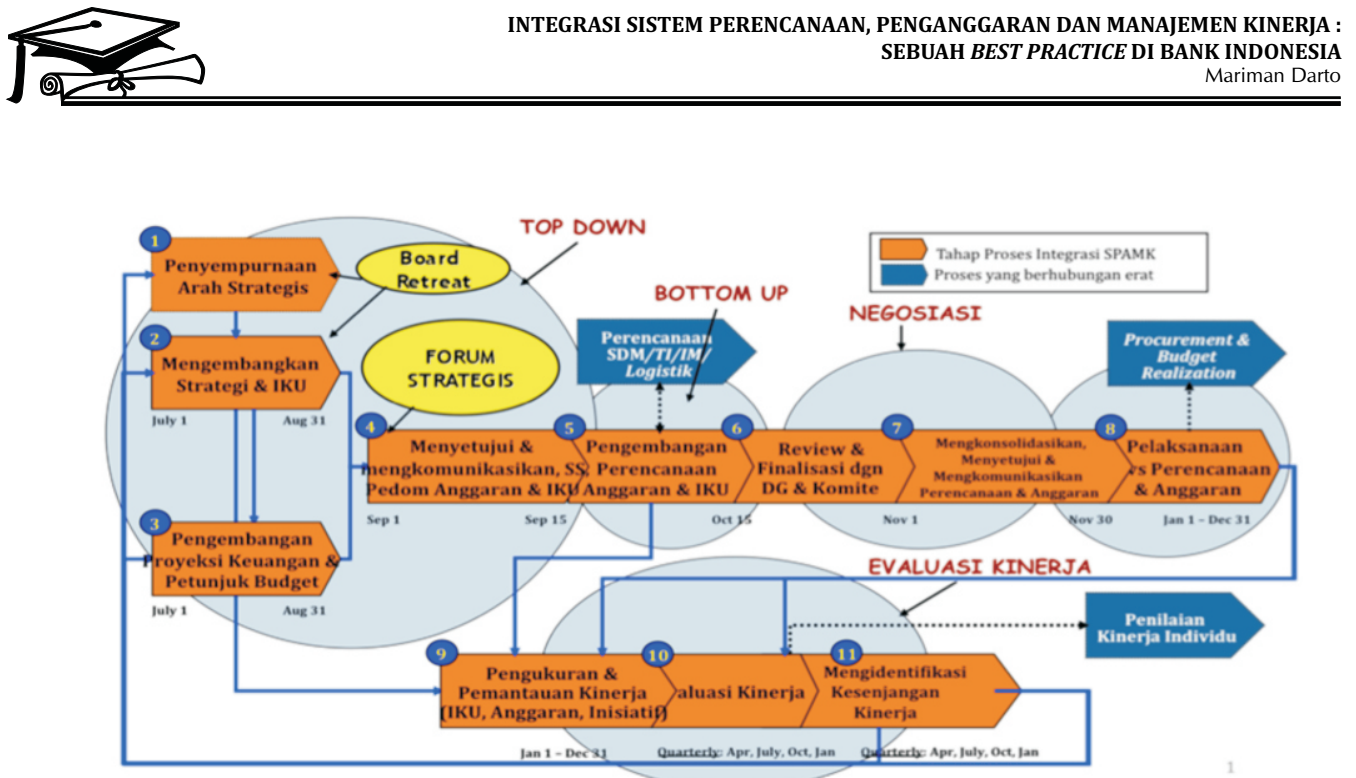

Sumber : Aulia Pohan dan Tim SPAMK (2006). Diolah

Gambar 6. Siklus SPAMK Bank Indonesia

Di langkah ke-7, perencanaan strategis dan budget akan dikonsolidasikan, dan akan disampaikan ke Dewan Perwakilan Rakyat (DPR) untuk persetujuan. Setelah persetujuan DPR, perencanaan strategis dan budget akan dijalankan dan dipantau pelaksanaannya selama tahun berjalan. Langkah-langkah ini merupakan langkah baku yang telah berjalan dengan baik selama beberapa tahun terakhir sejak SPAMK diperkenalkan. Dalam proses ini, untuk pertama kalinya dalam sejarah $\mathrm{BI}$, proses penyusunan anggaran dikaitkan dengan pencapaian arah strategis BI dan juga satuan kerja, dan kinerja yang berkaitan dengan pencapaian arah strategis dan budget, baik di level BI keseluruhan maupun di level satuan kerja, dipantau secara disiplin melalui Aplikasi Manajemen Kinerja (AMK$\mathrm{BI})$.

Secara umum integrasi sistem perencanaan, penganggaran dan manajemen kinerja dilakukan dalam sebelas tahapan. Kesebelas tahapan tersebut adalah sebagai berikut : (1) Penyempurnaan arah strategis; (2) Mengembangkan Strategi dan indikator kinerja utama (IKU); (3) pengembangan proyeksi keuangan dan petunjuk budget; (4) Menyetujui dan mengkomunikasikan sasaran Strategis, Pedoman Anggaran dan IKU; (5) Pengembangan Perencanaan, Anggaran dan IKU; (6) Review dan Finalisasi dengan Dewan Gubernur dan Komite; (7) Mengkonsolidasikan, menyetujui dan mengkomunikasikan perencanaan dan anggaran; (8) pelaksanaan rencana dan penganggaran; (9) Pengukuran dan pemantauan kinerja (IKU, Anggaran dan Inisiatif); (10) Evaluasi kinerja dan terakhir, (11) Mengidentifikasi kesenjangan kinerja (performance gaps).

Jika dikelompokkan ke dalam fungsi manajemen, maka proses perencanaan dilakukan sejak tahap pertama yakni penyempurnaan arah strategis sampai dengan tahap yang ketujuh : mengkonsolidasikan, 
menyetujui dan mengkomunikasikan perencanaan dan penganggaran. Meskipun demikian, pada tahapan akhir perencanaan ini sering disebut sebagai tahap penyusunan output perencanaan atau yang jamak kita sebut sebagai tahapan penganggaran. Tahap kedelapan adalah tahap pelaksanaan rencana dan penganggaran. Pada fungsi manajemen yang terakhir adalah tahapan mengintegrasikan tahapan perencanaan dan penganggaran yakni tahap evaluasi kinerja organisasi yang dilakukan dengan melakukan pengukuran dan pemantauan kinerja (IKU, Anggaran, Inisiatif) sebagai tahap ke-9. Tahap ini sering disebut sebagai tahapan perencanaan kinerja karena prosesnya dikaitkan dengan tahapan kelima perencanaan yakni pengembangan perencanaan, anggaran dan IKU. Proses selanjutnya adalah evaluasi kinerja (10) dan terakhir adalah tahapan mengidentifikasi kesenjangan kinerja.

\section{E. P E N U T U P : S E B U A H INFERENSI}

Pertama, dilihat dari desain dan pengembangan konsep SPAMK terlihat bahwa proses perencanaan hingga penganggaran merupakan konsep replikasi dari apa yang disebut sebagai perencanaan strategis dalam konsep Pedoman Penyusunan Rencana Strategis Kementerian/Lembaga (Renstra KL) 2010 - 2014, sebagaimana yang diatur dalam Peraturan Menteri Negara Perencanaan Pembangunan Nasional/Kepala Badan Perencanaan Pembangunan Nasional No. 5 Tahun 2009. Secara umum komponen perencanaannya juga berisi visi, misi, tujuan, strategi, kebijakan serta program dan kegiatan kementerian/lembaga, hanya saja pada visi penulisannya diletakkan setelah misi. Yang membedakannya adalah tidak adanya BSC dalam konsep Renstra versi pemerintah ini, sehingga kelemahan ini bisa berdampak efektifitas pencapaian sasaran stratejik menjadi kurang maksimal. Apalagi B S C m e miliki fung s i mengkomunikasikan strategi sekaligus sebagai penghubung antara Top Manager yang merupakan pemilik strategi dengan pelaksana strategi.

Kedua, adanya proses internal manajemen yang berdiri sendiri yang kegiatannya mengikuti proses perencanaan, penganggaran dan manajemen kinerja, sebagai berikut:

- Pertama, lahirnya Board Retread. Board Retread adalah forum penggalian pandangan dan pemikiran anggota Dewan Gubernur terhadap isu-isu strategis Bank Indonesia dan antisipasinya. Di forum itu, Arah strategis Bank Indonesia dibahas, disempurnakan dan ditinjau kembali, dengan mempertimbangkan perubahan kondisi eksternal yang paling berpengaruh terhadap kinerja Bank Indonesia.

- Forum strategis (Forstra). Forum yang dihadiri anggota Dewan Gubernur dan pimpinan satuan kerja yang dianggap dapat mewakili seluruh pelaksanaan tugas BI, untuk membahas dan menyusun strategi jangka pendek/tahunan, jangka menengah dan jangka panjang, usulan inisiatif dan IKU BI termasuk target dan evaluasi kinerja BI.

- Perencanaan SDM, Information Technology (IT), Information Management (IM) dan logistik 
dilakukan secara bersamaan dengan t a hapan pengembangan perencanaan dan penganggaran dan IKU. Hal ini memungkinkan adanya harmonisasi kebijakan perencanaan dan penganggaran yang secara umum dilakukan oleh komite dengan kebijakan pengembangan SDM, IT, IM dan logistik yang sangat dibutuhkan untuk menunjang pelaksanaan tugas pokok dan fungsi Bank Indonesia.

- Realisasi pengadaan dan anggaran menjadi proses terpisah. Harapannya adalah agar Komite Perencanaan, Anggaran dan Manajemen Kinerja yang bertanggungjawab atas integrasi SPAMK dapat bertanggungjawab atas keseluruhan sistem sejak awal perencanaan, penganggaran hingga pelaksanaan manajemen kinerja. Dengan demikian proses pengadaan dan penganggaran menjadi pekerjaan unit khusus, namun tetap diperlukan dalam mendukung pelaksanaan SPAMK.

- Penilaian kinerja individu. Penilaian kinerja individu merupakan penilaian terhadap kinerja seorang pegawai untuk satu periode waktu tertentu. Penilaian dilakukan dengan membandingkan antara target kinerja individu sesuai dengan kontrak kinerja individu yang telah ditetapkan sebelumnya dengan realisasi target yang dicapai. Proses ini berjalan bersamaan dengan evaluasi kinerja yang dilakukan secara kuartalan pada bulan Agustus, Juli, Oktober dan Januari.

Pelajaran penting apa yang bisa diperoleh dari pelaksanaan SPAMK adalah sebagai berikut:

Pertama, terintegrasinya sistem perencanaan, penganggaran dan manajemen kinerja memungkinkan penilaian kinerja organisasi tidak hanya didasarkan atas financial performance yang lebih menekankan pada efisiensi biaya, tetapi lebih kepada managerial performance yang lebih menitikberatkan pada output.

Kedua, sistem perencanaan dan penganggaran yang terintegrasi dengan manajemen kinerja memungkinkan kinerja seseorang terpantau secara obyektif.

Ketiga, sistem ini mampu meningkatkan aspek good governance karena penilaian kinerja menjadi lebih transparan dan akuntabel, serta dapat lebih mengedepankan keseimbangan antara proses dan outcome.

Keempat, terintegrasinya sistem ini dengan information technology memungkinkan proses manajemen berjalan secara obyektif dalam suatu dashboard system. Dewan Gubernur dan pimpinan satuan kerja dapat memantau kinerja organisasi setiap saat. Sistem ini dilengkapi dengan tiga indikator hijau, kuning dan merah. Indikator hijau menunjukkan keberhasilan dalam mencapai target. Indikator kuning mencerminkan early warning terhadap kemungkinan tidak tercapainya suatu target. Sedangkan indikator merah mencerminkan kegagalan dalam mencapai suatu target. Selain dapat mencerminkan kinerja organisasi, dashboard system ini juga berfungsi sebagai early 
warning system yang mendukung SPAMK sebagai management tools dan communication tools, termasuk mendukung proses pengambilan keputusan di Bank Indonesia. Untuk itulah SPAMK sangat mungkin bisa dilaksanakan di instansi pemerintah.

\section{DAFTAR PUSTAKA}

Amstrong, M., 1994, Performance Management, London: Kogen Page. Ltd.

Bastian, Indra, 2006, Sistem Perencan a a $n$ an Penganggaran Pemerintah Daerah di Indonesia, Jakarta: Penerbit Salemba Empat, Hal. 3 dan 10 .

Bates, R.A and Holton E.F., 1995, Computerized Performance Monitoring: Review of Human Resource Issues, dalam Human Resource Management Review. Winter, P. 267-288.

Brumbach, G.B., 1998, Some Ideas, Issues and Predictions about Performance Management, dalam Public Personnel Management. Winter, P. 387404.

http://www.bi.go.id/NR/rdonlyres/86 CE0C47-626D-49A6-989C125F12C9F938/18311/02 misi visi rev1.pdf/ diunduh pada 16 Nopember 2011.

http://www.bi.go.id/NR/rdonlyres/86 CE0C47-626D-49A6-989C125F12C9F938/18312/03_statu s_tujuan_rev1.pdf/ diunduh tanggal 16 Nopember 2011.

http://www.bi.go.id/web/id/Tentang + B I / Fung si+ Bank+Indonesia/Tujuan+dan+T ugas/ diunduh pada tanggal 16 Nopember 2011.

Kaplan, RS. and Norton DP., 1992, "The Balanced Scorecard: measures that drive performance", dalam Harvard Business Review, Jan-Feb.

LAN, 2005, Kajian Evaluasi Kebijakan Pengembangan dan Pelaksanaan SAKIP dan LAKIP, Jakarta: LAN.

LAN, 2006, Kajian Penyempurnaan SAKIP Sesuai Dengan Terbitnya Peraturan Pemerintah Nomor 8 Tahun 2006 tentang Pelaporan Keuangan dan Kinerja Instansi Pemerintah, Jakarta: LAN.

LAN, 2008, Kajian Penyusunan Pedoman Penerapan Manajemen Kinerja pada Instansi Pemerintah, Jakarta: LAN.

LAN, 2009, Kajian Penyusunan Modul Penerapan Manajemen Kinerja pada Instansi Pemerintah, Jakarta: LAN.

LAN, 2010, Kajian Penerapan Manajemen Kinerja, Jakarta: LAN.

Pohan, Aulia dan Tim SPAMK, 2006, Towards High Performance Organization: Perjalanan Bank Indonesia dalam Mengelola 
Strategi dan Kinerja, Jakarta : Bank Indonesia.

Sancoko, Bambang, dkk., 2008, Kajian Terhadap Penerapan Penganggaran Berbasis Kinerja di Indonesia, Jakarta: Balai Diklat Keuangan, Departemen Keuangan.

Waal, Andre de, 2007, Strategic Performance Management: A Managerial and Behavioural Approach, New York: Palgrave Macmillan, P.19.

\section{Peraturan Perundang-undangan}

UU No. 17 Tahun 2003 tentang Keuangan Negara;

UU No. 25 Tahun 2004 tentang Sistem Perencanaan Pembangunan Nasional;

UU No. 32 Tahun 2004 tentang Pemerintahan Daerah;

UU No. 33 Tahun 2004 tentang Perimbangan Keuangan Pusat dan Daerah.

UU No. 1 Tahun 2004 tentang Perbendaharaan Negara;

UU No. 15 Tahun 2004 tentang Pemeriksaan Pengelolaan dan Tanggungjawab Keuangan Negara;

PP 108/2000 tentang Tatacara Pertanggungjawaban Kepala Daerah

PP No. 20 Tahun 2004 tentang Rencana Kerja Pemerintah;
PP No. 21 Tahun 2004 tentang Rencana Kegiatan dan Anggaran Kementerian Negara/Lembaga;

PP No. 58 Tahun 2005 tentang Pengelolaan Keuangan Negara;

PP No. 8 Tahun 2006 tentang Pelaporan Keuangan dan Kinerja Instansi Pemerintah,

PP No. 39 Tahun 2006 tentang Tata Cara Pengendalian dan Evaluasi Pelaksanaan Rencana Pembangunan,

PP No. 40 Tahun 2006 tentang Tata Cara Penyusunan Rencana Pembangunan Nasional,

PP No. 8 tahun 2008 tentang Tahapan Tata $\mathrm{C}$ a $\mathrm{r}$ a , $\mathrm{P}$ e $\mathrm{n}$ y $\mathrm{u}$ s $\mathrm{u}$ n a $\mathrm{n}$, Pengendalian dan Evaluasi Pelaksanaan Rencana Pembangunan Daerah,

Perpres No. 24 Tahun 2010 tentang Kedudukan, Tugas, dan Fungsi Kementerian Negara serta Susunan Organisasi, Tugas dan Fungsi Eselon I Kementerian,

Perpres No. 81 Tahun 2010 tentang Grand Design Reformasi Birokrasi Tahun 2010-2025.

Instruksi Presiden RI No. 5 Tahun 2004 $\mathrm{tentang} \quad \mathrm{Percepatan}$ Pemberantasan Korupsi;

Inpres 7/1999 tentang Akuntabilitas Kinerja Instansi Pemerintah;

Peraturan Menteri Negara Perencanaan 
Pembangunan Nasional/Kepala B a d a $\mathrm{n}$ P e r e n c a n a $n$ Pembangunan Nasional Nomor: 5 Tahun 2009 tentang Pedoman Penyusunan Rencana Strategis Kementerian/Lembaga (Renstra KL) 2010-2014.

Peraturan Menteri PAN dan RB No. 29

Tahun 2010 tentang Pedoman
Penyusunan Penetapan Kinerja dan Pelaporan Akuntabilitas Kinerja Instansi Pemerintah.

Surat Edaran Menpan No. SE/31/M.PAN/12/2004 tentang Penetapan Kinerja.

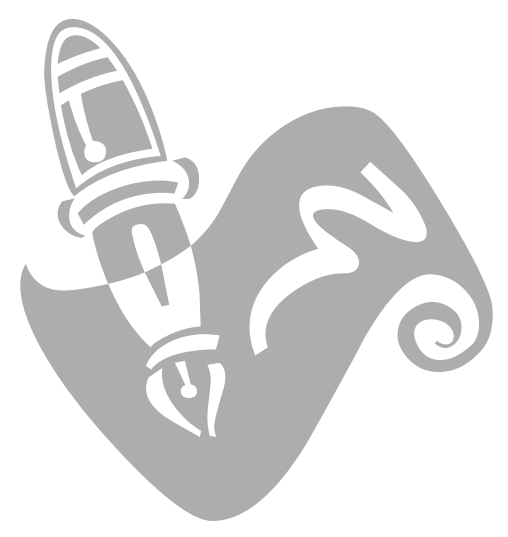

